\title{
Pemanfaatan Pengguna Handpone Pada Masyarakat Desa Keleyan Kecamatan Socah Kabupaten Bangkalan
}

Nova dastiyana

Program Studi Manajemen Fakultas Ekonomi dan Bisnis

Universitas Trunojoyo Madura

\begin{tabular}{|c|c|c|}
\hline INFO ARTIKEL & \multicolumn{2}{|c|}{ Abstract } \\
\hline \multicolumn{3}{|l|}{$\begin{array}{l}\text { Sejarah Artikel: } \\
\text { Diterima : } \\
\text { Diperbaiki : } \\
\text { Disetujui } \quad: \\
\text { Keywords: }\end{array}$} \\
\hline & \multicolumn{2}{|c|}{ Abstraks } \\
\hline $\begin{array}{l}\text { Kata Kunci: } \\
\text { pemanfaatan handpone, } \\
\text { komunikasi,masyarakat } \\
\text { pedesaan } \\
\text { DOI: }\end{array}$ & \multicolumn{2}{|c|}{$\begin{array}{l}\text { Perkembanga teknologi jaman sekarang semakin berkembang dan } \\
\text { semakin canggih, masyarakat jaman sekarang banyak yang } \\
\text { menggunakan handpone sebagai alat komunikasi. Handpone adalah } \\
\text { parangkat telekomunikasi elektronik yang mempunyai kemampuan } \\
\text { dasar yang sama dengan handpone konvensional saluran tetap,namun } \\
\text { dapat dibawa kemana -mana dan tidak perlu di sambungkan dengan } \\
\text { jaringan telepon menggunakan kabel.handpone telah merubah perilaku } \\
\text { komunikasi manusia dengan menembus ruang dan waktu. Banyak } \\
\text { sekali dampak positif dan negative dari penggunaan handpone. Saat } \\
\text { ini perkembangan tekhnologi handpone sangat berkembang pesat. } \\
\text { Hampir semua orang mempunyai handpene sebagai alat komunikasi } \\
\text { yang sangat mudah digunakan oleh masyarakat Indonesia, handpone } \\
\text { ini tidak hanya sebagai alat komunikasi semata,tetapi saat ini dapat } \\
\text { dimanfaatkan sebagai multimedia dan salah satunya dapat } \\
\text { dimanfaatkan dalam dunia pendidikan. handphone memang } \\
\text { berdampak positif terhadap masyarakat desa terutama dalam rangka } \\
\text { menjaga tetap terjalinnya hubungan komunikasi dengan orang-orang } \\
\text { teristimewa kerabat atau famili yang berada jauh di luar daerah. } \\
\text { Namun di dalam kapasitas sebagai smartphone dengan berbagai fitur } \\
\text { yang dimilikinya sebagai sumber informasi ternyata hal itu } \\
\text { belum banyak diketahui pemanfaatannya oleh masyarakat desa. }\end{array}$} \\
\hline \multicolumn{2}{|c|}{$\begin{array}{l}\text { Koresponsi: } \\
\text { Nama: Nova dastiyana } \\
\text { Email: dastyanan@gmail.com p-ISSN: 2355-9543 } \\
\text { email dastyanan@gmail.com }\end{array}$} & $\begin{array}{l}\text { ISSN: } \\
\text { 2355-9543(Print) } \\
\text { ISSN: 2460-3775 } \\
\text { (on-line) }\end{array}$ \\
\hline
\end{tabular}

\section{PENDAHULUAN}

Di era sekarang, segala sesuatu dapat diselesaikan dengan cara-cara yang praktis. Hal ini merupakan dampak yang timbul dari hadirnya teknologi.
Teknologi adalah sesuatu yang bermanfaat untuk mempermudah semua aspek kehidupan manusia. Dunia informasi saat ini seakan tidak bisa terlepas dari teknologi. Penggunaan teknologi oleh 


\section{Jurnal Studi Manajemen dan Bisnis}

Vol. 5 (2) 2018

masyarakat menjadikan dunia teknologi semakin lama semakin canggih. Awalnya, teknologi diciptakan untuk mempermudah setiap kegiatan manusia. Teknologi lahir dari pemikiran manusia yang berusaha untuk mempermudah kegiatankegiatannya yang kemudian diterapkan dalam kehidupan. Menggunakan teknologi komunikasi, seperti handphone dan internet sebagai alat multifungsi, karena multifungsinya tersebut masyarakat dapat menggunakan teknologi ini secara positif ataupun negatif tergantung setiap individu. Contoh positif dari penggunaan teknologi komunikasi adalah memanfaatkan teknologi ini untuk membantu mereka dalam proses interaksi dengan keluarga, proses ekonomi/perdaganngan atau bisnis dan juga proses pembelajaran atau terkait dengan pengembangan dunia pendidikan. Namun, ada beberapa hal yang perlu dikhawatirkan dalam pemanfaatan teknologi komunikasi oleh masya-rakat seperti penggunaan tidak sesuai kondisi. Misalnya, menggunakan handphone dalam proses belajar mengajar untuk

\section{TINJAUAN PUSTAKA DAN TEORI}

\section{A. KONSEP KOMUNIKASI}

1. pengertian komunikasi

komunikasi merupakan alat penghubung antara orang yang satu dengan yang lainnya,meskipun tidak tinggal dalam satu desa masyarakat tetap bisa berkomunikasi dengan jarak jauh dengan memanfaatkan tekhnologi yang ada yaitu dengan berkomunikasi menggunakan handpone, dengan handpone masyarakat dapat dengan mudah berkomunikasi misalnya dengan menelpon/ mengirimkan sms. penggunaan informasi atau pesan yang dikeluarkan secara verbal atau non verbal didalam hingkup atau lingkungan organisasi.untuk mencapai sebuah komuniasi yag efektif perlu pengonsepan yang digunakan dengan baik agar mendapatkan hasil yang memuaskan.

pengertian komunikasi menurut para ahli;

1. achmad s. ruky

komunikasi merupakan proses pemindahan dan pertukaran dan pemindahan pesan, dimana pesan ini dapat berbentuk fakta, gagasan,perasaan, data atau informasi dari seorang kepada orang lain. proses ini bertujuan untuk mempengaruhi / merubah informasi yang dimiliki serta tingkat laku orang yang menerima pesan tersebut.

2. anderson

komunikasi merupakan proses yang dinamis. proses ini secara konstan merubah sesuai dengan situasi yang berlaku

3. atep aditya barata

komunikasi sebagai proses pengiriman dan sms-an dengan pacar atau menggunakan fasilitas internet untuk mengakses situs-situs porno, dan lain-lain. Kini teknologi telah berkembang pesat dan semakin canggih seiring dengan perkembangan zaman sehingga terjadi penambahan fungsi teknologi yang semakin memanjakan kehidupan manusia. Karena hampir semua masyarakat memiliki handpone. Masyarakat lebih tertarik dan lebih banyak memiliki handpone dari pada alat komunikasi lainnya, karena mudah dibawa kemana-mana dan dapat digunakan kapan saja dan dapat dibawa kemana saja dapat digunakan saat dibutuhkan.pada saat ini permintaan masyarakat terhadap handpone semakin meningka, hal ini merupakan peluang besar bagi produsen untuk menciptakkan inovasiinovasi baru pada handpone. Salah satu produsen hanpone saat ini yang di segani adalah Samsung dan oppo.

penerimaan pesan,berita atau informasi yang terjadi diantara dua orang atau lebih. proses ini dilakukan secara efektif agar pesan yang disampaikan sampai kepada penerimanya.

2. komunikasi masa

pada bagian lain jalaluddin rakhmad, (1989:213-

214) telah mengumpulkan beberapa definisi mengenai komunikasi dari pendapat para ahli komunikasi massa sebagi berikut:

a. komunikasi massa adalah pesan yang dikomunikasikan melalui media massa, melalui sejumlah besar orang. (bitner).

b. komunikasi massa adalah produksi dan distribusi yang berlandaskan teknologi dan lembaga dari arus yang continue serta paling luas dimiliki orang dalam masyarakat industry. (gerbner)

c. komunikasi massa kita artikan setiap bentuk komunikasi yang menyampaikan pesan komunikasi secara terbuka melalui media penyebaran teknik, secra tidak langsung dan satu arah pada public yang tersebar. (maletzke)

d. komunikasi massa dibedakan dari jenis komunikasi lainnya dengan suatu kenyataan bahwa komunikasi massa dialamatkan kepada sejumlah polulasi dari kelompok, dan bukan hanya satu atau beberapa individu atau sebagian khusus populasi. komunikasi massa juga menyampaikan pesan komunikasi agar supaya komunikasi itu dapat mencapai pada saat yang sama pada semua orang yang mewakili berbagai lapisan masyarakat. (freidsow) 


\section{Pemanfaatan Pengguna Handpone Pada Masyarakat Desa Keleyan,.. Nova dastiyana}

e. bentuk komunikasi dapat dibedakan dari corak-corak yang lama karena memiliki karateristik utama sebagai berikut : diarahkan pada khalayak yang relatif lebih besar; heterogen, anonym, pesan disampaikan secara terbuka, sering kali dapat mencapai kebanyakan khalayak secara serentak, bersifat sekilas, komunikator cenderung berada atau bergerak dala organisasi yang kompleks, melibatkan biaya besar. (wright).

$\mathrm{f}$

b. konsep handpone

saat ini indonesia mempunyai dua jaringan telepon nirkabel yaitu sistem gsm (global system for mobile telecommunications) dan sistem cdma (code division multiple access). badan yang mengatur telekomunikasi seluler indonesia adalah asosiasi telekomunikasi seluler indonesia (atsi).

telepon seluler (ponsel) atau telepon genggam (telgam) atau handphone (hp) atau disebut pula adalah perangkat telekomunikasi elektronik yang mempunyai kemampuan dasar yang sama dengantelepon konvensional saluran tetap, namun dapat dibawa kemana-mana (portabel, mobile) dan tidak perlu disambungkan dengan jaringan telepon menggunakan kabel.

c. manfaat dan fungsi handpone

selain berfungsi untuk melakukan dan menerima panggilan telepon, ponsel umumnya juga mempunyai fungsi pengiriman dan penerimaan pesan singkat (short message service, sms)selain itu handpone mempunyai banyak fitur dan aplikasi. aplikasi yang banyak di gunaakan saat ini diantaranya (ig,wa,fb,twitter) dll. aplikasi ini sangat membantu dalam melalukan komunikasi menggnakn telepon. fungsi telepon juga sebagai komunikasi jarak jauh, bisa digunakan untuk mencari informasi di media sosial bisa menambah dan mencari teman bisa juga untuk usaha biisnis melalui online.

manfaat dan fungsi handpone

1. komunikasi antar manusia

dengan adanya hanpone kita bisa melakukan komunikasi setiap harinya meskipun kita berasa berjauhan bisa berkomunikasi melalui (ig,wa,fb,twitter) dll. tidak perlu datang kerumahnya cukup gunakan handpone semua pesan yang ingin di sampaikan akan sampai kepada orang yang dituju.

2. media hiburan

banyak fitur / aplikasi yang terdapat didalan hanphone tersebut, misalkan aplikasi tik tok yang sedang hits dikalangan masyarakat, dengan mendowload aplikasi tersebut kalian bisa menggunakan sebagai media hiburan dikala waktu senggang, dengan membuat video menggunakan tik-tok lkalian akan merasa terhibur karena banyak sekali video-vidio lucu yang disajikan dalam aplikasi tersebut

\section{3. penyimpana data dan foto}

hanpone bisa digunakan sebagai alat untuk menyimpan data-data penting dan foto kalian, data tugas kuliah bisa di simpan dengan aman di dalam handpone tersebut, tidak perlu susah payah menyimpan di laptop,simpan di handpone jauh lebih gampang.

4. sebagai alat pembelajaran

dengan menggunakan hanpdone kita lebih mudah untuk memahami sesuatu yang belum pernah kita pahami, karena didalam handpone terdapat aplikasi google yang menbantu kita untuk mempermudah kita mengatahui pelajaran yang belum pernah kita ketahui sebelumnya.

d. pola penggunaan handphone pada masyarakat di perdesaan

masyarakat mempergunakan handphone saat berada di rumah, ditempat usaha / di kantor dan menggunakan perangkat handphone saat berada disekolah. dilihat dari frekuensi penggunaannya penggunaan fitur sms menjadi pilihan dalam penggunaan perangkat handphone menunjukan pemakaian yang tidak begitu tinggi, dimana dalam satu minggu rata-rata hanya menggunakan perangkat handphone untuk kegiatan panggilan atau menerima telephone. namun demikian terdapat durasi waktu yang cukup lama didalam mempergunakan handphone, dimana aktifitas pemakaian handphone mencapai 15 menit dalam satu kali pemakaai.

e. masyarakat

masyarakat merupakan istilah yang sudah lazim digunakan untuk menyebutkan

kesatuan-kesatuan hidup manusia, baik dalam tulisan-tulisan maupun bahasa sehari- hari. dalam bahasa inggris istilah "society" yang berasal dari bahasa latin "socius" yang berarti kawan, dalam bahasa arab "syrik" yang berarti bergaul.

masyarakat merupakan sekumpulan manusia yang saling bergaul atau istilah ilmiah saling berinteraksi, (pengantar antropologi fh unsrat (1990:30:32). m. m. djojodinegoro guru besar sosiologi ugm dalam bukunya "azas-azas sosiologi" (1959: 2l) menyatakan konsep masyarakat dalam arli luas adalah masyarakat indonesia sedangkan masyarakat dalam aarti sempit adalah masyarakat adat serta identitas komunitas lain dan rasa loyalitas terhadap komunitas yang besar sebagai 


\section{Jurnal Studi Manajemen dan Bisnis \\ Vol. 5 (2) 2018}

suatu kesatuan hidup manusia yang menempati suatu wilayah yang nyata dan berinteraksi menurut suatu sistem adat istiadat serta terikat oleh suatu identitas komunitas. masyarkat adalah suatu kesatuan hidup manusia yang bersifat mantap dan terikat oleh kesatuan adat dan rasa identitas bersama, maka dapat dikatakan bahwa persepsi masyarakat pengguna/pemakai perpustakaan adalah tanggapan, penilaian, pengamatan, cara pandang, atau pembentukan kesan terhadap sebuah objek oleh sekelompok.

\section{METODE}

Metode deskriptif adalah bertujuan untuk memaparkan situasi dan peristiwa. Metode

deskriptif tidak mencari atau meneliti hubungan antara variabel-variabel. Tujuan penelitian dekriptif adalah untuk membuat dekripsi, gambaran, atau lukisan secara sistematis, faktual dan akurat serta fakta-fakta, sifat-sifat serta hubungan antara fenomena yang diselidiki. Variabel penelitian dalam penelitian ini adalah variabel tunggal yaitu pemanfaatan penggunaan hanphone pada masyarakat desa Keleyan Kecamatan Socah Kabupaten Bangkalan Indikator dalam penelitian ini adalah sebagai berikut:

- Pemahaman tentang handpone

- Cara menggunakan handpone

- Manfaat handphone bagi masyarakat

Dalam penelitian ini yang menjadi populasi adalah masyarakat yang ada di Desa Keleyan Kecamatan Socah Kabupaten Bangkalan, yang berjumlah 326 orang, diambil dari 10\% masyarakat keseluruhan yang ada di desaPiungun tersebut adalah: 32 orang sebagai responden dalam penelitian ini.

Untuk mendukung penelitian ini, peneliti menggunakan teknik analisis deskriptif. Dimana data yang sudah ada diperoleh dari interview dan proses menjalankan quisioner kemudia diolah dengan table frekuensi dan porsentase setelah itu di gambarkan dan dideskripsikan dalam bentuk kalimat, dan untuk hasil wawancara digunakan untuk menjelaskan hasil penelitian yang diperoleh dengan kuisioner dan angket.

\section{PEMBAHASAN}

Kemajuan teknologi yang begitu pesat saat ini ternyata juga semakin cangihnya alat

komunikasi seperti handphone. Handphone merupakan alat komunikasi tanpa kabel yang sering disebut telepon genggam, karena jenis telepon ini sengaja dirancang untuk kemudahan pemakai yang dapat menunjang mobilitasnya.
Media sosial memang merupakan salah satu faktor penyebab mengapa banyak masyarakat yang ingin memiliki smartphone. Berdasarkan survei Mobile Web Watch 2013, media sosial mendominasi cara berkomunikasi online generasi muda (usia 14-39 tahun). Sebanyak 40 persen menggunakannya setiap hari lebih sering daripada pesan instan (35 persen) dan email (30 persen) Perkembangan terkini ponsel tidak hanya sebagai alat mengobrol, namun dilengkapi dengan fitur-fitur canggih lain seperti, video streaming, MMS, games, kamera, PDA dan fasilitas web (Misky, 2005: 67). Kebutuhan akan komunikasi membuat setiap orang merasa keberadaan alat penunjang komunikasi sangat diperlukan. Di Desa Keleyan Kacamata Socah Kabupaten Bangkalan banyak sekali pengguna handpone kurang lebih hampir 99\% menggunakan handpone sebagai alat untuk berkomunikasi dengan keluarga Demi tujuan untuk memperlancar komunikasi tersebut, sehingga saat ini alat komunikasi seperti handphone juga mengalami perkembangan menjadi smartphone.

Handphone dapat dikatakan sebagai teknologi yang akan menyingkirkan komputer desktop ke depannya terutama dalam masalah pengaksesan data dari internet. Smartphone saja, versi "pintar" nya handphone, sudah semakin lumrah di Indonesia. Pada tahun 2000-an awal hanya orangorang kaya saja yang memakai smartphone. Smartphone masih dianggap sebagai barang mewah dan belum terjangkau oleh berbagai kalangan masyarakat, namun sekarang smartphone sudah bisa dibeli oleh berbagai golongan (teknojurnal.com). Salah satunya yaitu oleh remaja yang merupakan pengguna media sosial di internet dan memiliki smartphone sudah bukan hal yang baru bagi mereka. Dalam smartphone juga terdapat berbagai fasilitas

atau aplikasi seperti game-game menarik yang bisa diunduh secara gratis. Cara memainkan games inipun mudah dan dengan mengunakan smartphone, games ini bisa dimainkan kapan saja dan dimana saja. Bagi mereka games dalam smartphone merupakan hiburan yang mudah dan murah saat sedang jenuh.

Kebanyakan masyarakat Masyarakat Desa Keleyan Kecamatan Socah Kabupaten Bangkalan menggunakan handphone sebagai media komunikasi antar keluarga. Masyarakat Desa Keleyan Kecamatan Socah Kabupaten Bangalan 


\section{Pemanfaatan Pengguna Handpone Pada Masyarakat Desa Keleyan,.. Nova dastiyana}

pernah menggunakan handphone sebagai media informasi.

Hasil penelitian tentang apakah handphone digunakan sebagai media hiburan, ternyata masyarakat desa piungun masih belum memanfaatkan handphone tersebut sebagai media hiburan bagi mereka. Padahal didalam fitur sebuah handphone terdapat aplikasi yang bisa memutar lagu dan video.

Berdasarkan data tentang pengukuran indikator apakah handphone dijadikan sebagai media peyimpanan data, dapat disimpulkan bahwa rata-rata masyarakat menggunakan handphone untuk keperluan menyimpan data dan komunikasi Handphone sebagai bagian dari gaya atau life style, atau istilah kerennya untuk gaya-gaya'an, sangat tinggi digunakan oleh Masyarakat Desa Keleyan Kecamatan Socah Kabupaten Bangkalan Dari hasil penelitian menunjukkan bahwa masyarakat Desa Keleyan memanfaatkan handphone tersebut sebagai alat untuk berkomunikasi. Pemanfaatan handphone oleh masyarakat Masyarakat Desa Keleyan Kecamatan Socah Kabupaten Bangkalan adalah cukup sering menggunakan handphone tersebut untuk berkomunikasi dengan keluarga.

\section{SIMPULAN DAN SARAN}

\section{Kesimpulan}

Kesimpulan

1. Pemanfaatan handphone bagi masyarakat khususnya pada masyarakat Desa Keleyan Kecamatan Socah Kabupaten Bangkalan, dapat dikategorikan positif namun belum dioptimalkan secara keseluruhan mengenai fungsi-fungsi handphone tersebut dalam meningkatkan komunikasi dan informasi.

2. Pemanfaatan handphone bagi masyarakat Desa Keleyan Kecamatan Socah Kabupaten Bangkalan, masih dalam kapasitas untuk berkomunikasi dengan anggota keluarga.

3. Masyaraka banyak yang memanfaatnkan handpone tersebut sebagai alat untuk berkomunikasi dengan keluarganya.

4. Masyarakat sudah bisa menggunakan aplikasi / fitu-fitur yang ada di dalam handpone tersebut.

\section{Saran}

Dari hasil kesimpulan penelitian diatas, dapatlah menjadi acuan untuk memberikan saran sebagai berikut:

1. Masyarakat harus bisa menggunakan handpone tersebut dengan bijak jangan menggunkan handpone tersebut untuk merugikan orang lain, jdi handpone tersebut harus di manfaatkan dengan sebaik mungkin.

2. Diperlukan peran serta pemerintah setempat guna memberikan pelatihan tentang bagaimana cara menggunakan dan memaanfaatkan handphone yang benar dan baik guna meningkatkan fungsi komunikasi dan informasi bagi masyarakat desa tersebut

\section{DAFTAR PUSTAKA}

https:/ / googleweblight.com/i?u=https:/ / pakarko munikasi.com/pengertian-komunikasimenurut-para-ahli\&hl=idIDhttp://eprints.ums.ac.id/34128/8/03.\%20B $\mathrm{AB} \%$ 201.pdf

http:/ / ungukampus.blogspot.com/2012/10/conto h-abstrak.html?m=1

http:/ / www.komunikasipraktis.com/2015/04 / komunikasi-massa-pengertian.html?m=1

http:/ / arumdeapikat.blogspot.com/2011/04/manf aat-handphone-bagikehidupan.html.7 https://id.m.wikipedia.org/wiki/portal:masy arakat 